\title{
Fetomaternal outcome in sickle cell hemoglobinopathy in a tertiary care centre of North Kerala, India
}

\author{
Smitha D'Couth, Suneetha Kalam*
}

Department of Obstetrics and Gynecology, Government Medical College, Kozhikode, Kerala, India

Received: 12 November 2017

Accepted: 17 November 2017

\section{*Correspondence:}

Dr. Suneetha Kalam,

E-mail: suneethakalam@gmail.com

Copyright: (C) the author(s), publisher and licensee Medip Academy. This is an open-access article distributed under the terms of the Creative Commons Attribution Non-Commercial License, which permits unrestricted non-commercial use, distribution, and reproduction in any medium, provided the original work is properly cited.

\begin{abstract}
Background: Pregnancy is a serious burden to women with sickle cell disease (SCD). Our centre is the only tertiary care referral centre in the public sector which caters to the districts of Wayanad and the Nilgiris which has the maximum prevalence for SCD in South India. Hence this study was conducted to assess complications in pregnancy and maternal and perinatal outcome among women with SCD.

Methods: A retrospective observational study was conducted by reviewing the medical records of all the pregnant women with SCD who had delivered in the Department of Obstetrics and Gynecology, Government Medical College, Kozhikode from January 2014 to December 2016.

Results: There were 72 antenatal women with SCD during the study period with a prevalence of $0.15 \% .54 .17 \%(\mathrm{n}=$ 39) patients were HbSS (sickle cell anemia), 44.44\% $(\mathrm{n}=32)$ were HbAS (sickle cell trait) and $1.39 \%(\mathrm{n}=1)$ were $\mathrm{HbS}-\beta$ thalassemia trait. There was increased risk of obstetric complications like gestational hypertension (16\%), preeclampsia (11.11\%), eclampsia (5.56\%), HELLP syndrome (4.16\%), intrauterine growth retardation (38.89\%), and oligohydramnios (18.06\%). Medical complications observed were mainly anaemia (76.38\%), vasoocclusive crisis $(18.05 \%)$, acute chest syndrome $(5.56 \%)$ and infections like urinary tract infection $(8.33 \%)$ and pneumonia $(5.56 \%)$. The incidence of low birth weight babies (56.94\%), low Apgar score (14.49\%) and neonatal ICU admissions $(31.88 \%)$ were high. There was no maternal mortality, but perinatal mortality was high $(6.94 \%)$.

Conclusion: Pregnancy in SCD is associated with an increased maternal morbidity and high perinatal mortality due to obstetric and medical complications.
\end{abstract}

Keywords: Sickle cell disease (SCD), Maternal morbidity, Perinatal outcome

\section{INTRODUCTION}

Sickle cell disease (SCD) is a group of inherited singlegene autosomal recessive disorders caused by the 'sickle' gene, which affects hemoglobin structure. Sickle hemoglobin (hemoglobin $S$ ) originates from a single $\beta$ chain substitution of glutamic acid by valine, which stems from an A-for-T substitution at codon 6 of the $\beta$ globin gene. The term SCD includes sickle cell anaemia (HbSS) and combination of $\mathrm{HbS}$ with abnormal hemoglobins like hemoglobin $\mathrm{C}$ (giving HbSC), combination with beta thalassemia (giving $\mathrm{HbS}-\beta$ thalassemia) and combination with hemoglobin D, E or O-Arab. ${ }^{1}$ Hemoglobin $S$ combined with normal hemoglobin (A), known as sickle trait (AS), is usually asymptomatic, except for a possible increased risk of urinary tract infections and microscopic hematuria.

Sickle cell disease is the most common inherited disorder worldwide with varying clinical severity and potentially serious complications. ${ }^{2}$ SCD is prevalent in sub-Saharan Africa, South America, Central America, Saudi Arabia, 
India, and Mediterranean countries. ${ }^{3}$ Globally, India accounts for $14.5 \%$ of the total new-borns with SCD. ${ }^{4}$ The first description of sickle hemoglobin in India was by Lehman and Cutbush in 1952 in the tribal populations in the Nilgiri hills in South India. Many population groups have been screened in India and the sickle cell gene has been shown to be prevalent among three socioeconomically disadvantaged ethnic groups - the scheduled tribes, the scheduled castes and other backward classes. $^{5}$

The primary pathophysiology of SCD is due to the polymerization of $\mathrm{HbS}$ in low oxygenated conditions with formation of long fibers within the RBCs making them fragile and sickle shaped. These cells are prone to increased breakdown causing hemolytic anemia, and vaso-occlusion in the small blood vessels, resulting in most of the clinical features of this multi organ disease. Red cell dehydration, abnormal adhesion of RBCs to the vascular endothelium, inflammatory events, and activation of all the cells in the vessel and abnormalities of nitric oxide metabolism have been attributed to trigger a vasoocclusive event. ${ }^{6}$ Acute complications of SCD include ischemic, vasoocclusive (pain) crises, acute chest syndrome, stroke, splenic sequestration, acute renal failure, and cholecystitis. Chronic complications include chronic pain, cholelithiasis, renal dysfunction, hypertension, pulmonary hypertension, and retinal problems, leg ulcers and avascular necrosis of femoral and humerous head and increased propensity for infections and sepsis. ${ }^{7}$

Pregnancy in sickle cell women has numerous obstetrical, non-obstetrical, and fetal complications. SCD has been proposed to be a chronic inflammatory state. ${ }^{8}$ Endothelial damage secondary to sickled red blood cells and the subsequent release of proinflammatory cytokines may contribute to microvascular damage. Normal vascular, endothelial, and inflammatory adaptations in pregnancy may lead to exacerbation of these pathophysiologic changes, with manifestation of resulting maternal complications such as preeclampsia and fetal growth restriction. ${ }^{9}$ Maternal problems can arise from chronic underlying organ dysfunction such as renal disease or pulmonary hypertension, from acute complications of SCD such as vaso-occlusive crises and acute chest syndrome, and from pregnancy-related complications. The main maternal complications of pregnancies complicated by sickle cell disease are anemia, infection, vasoocclusive crisis, and preeclampsia. ${ }^{10}$ Fetal problems affecting perinatal outcome are intrauterine growth restriction, premature birth, abnormal fetal heart rate, and intrauterine fetal death. ${ }^{8}$ Complications of sickle cell disease precipitate preterm labour and increase the risk of caesarean section to improve the pregnancy outcome. ${ }^{11}$ High maternal and fetal mortality are seen in pregnant mothers with sickle cell disease. ${ }^{12}$
The aim of this study was to study the maternal and perinatal outcomes in pregnancies complicated by sickle cell disease.

\section{METHODS}

It was a retrospective observational study including all pregnant women with sickle cell disease after 20 weeks of gestation who had antenatal care and delivery in the Department of Obstetrics and Gynecology, Government Medical College, Kozhikode from January 2014 to December 2016. The information about each pregnancy was collected by reviewing all available medical records of these women.

The information recorded for each woman were age, parity, genotype of sickle cell disease and whether belonging to tribal population or not. Maternal morbidity was assessed by analyzing both medical and obstetric complications (anemia, infectious morbidity, sickle cell crises, IUGR, gestational hypertension, eclampsia, abruption, and preterm labour pain). Severity of anemia and the need for blood transfusion were analysed. Anemia among pregnant women was taken as hemoglobin level less than $11 \mathrm{~g} / \mathrm{dl}$, and severe anemia defined as hemoglobin level less than $7 \mathrm{~g} / \mathrm{dl}$. The details of labor as gestational age at delivery, whether induced or spontaneous, and mode of delivery were collected. The perinatal outcome was measured by analyzing the Apgar score, birth weight, and need for NICU admission and mortality. Low birth weight was defined as weight less than $2.5 \mathrm{~kg}$ and very low birth weight was defined as weight less than $1.5 \mathrm{~kg}$. These data were recorded in an Excel spreadsheet and later compiled for statistical analysis. Data are presented as descriptive statistics with frequencies and percentages.

\section{RESULTS}

There were 46,562 deliveries in the Department of Obstetrics and Gynecology during the period of 3 years from January 2014 to December 2016 of which 72 $(0.15 \%)$ were women with sickle cell disease. SCD accounted for $0.79 \%$ of the 9146 antenatal women complicated by anemia during the study period.

Age distribution of the patients ranged from 19 to 39 years with a mean of 26.6 years (Table 1). Majority $(63.89 \%)$ of the women with SCD were multiparous while $36.11 \%$ were nulliparous being primigravidae or with one or more previous abortions

Table 1: Age distribution.

\begin{tabular}{|lll|}
\hline Age group & Frequency $(\mathbf{n})$ & Percentage $(\%)$ \\
\hline$<20$ years & 3 & $4.12 \%$ \\
\hline 20-30 years & 57 & $79.17 \%$ \\
\hline$>30$ years & 12 & $16.67 \%$ \\
\hline
\end{tabular}


Of the study population, 90.27\% $(\mathrm{n}=65)$ women belonged to the tribal population with majority hailing from different areas of Wayanad district and 2 of them from Nilambur taluk of Malappuram district located close to the Nilgiris range of Western Ghats. Only $9.72 \%(\mathrm{n}=$ 7) patients were non-tribal of which 4 patients were from different areas close to the Nilgiris.

Genotypically $54.17 \%(\mathrm{n}=39)$ women were of $\mathrm{HbSS}$ (sickle cell anemia), $44.44 \%(n=32)$ were HbAS of (sickle cell trait) and $1.39 \%(n=1)$ were $\mathrm{HbS}-\beta$ thalassemia trait.

$83.33 \%(n=60)$ were diagnosed cases of sickle cell disease, while $16.67 \%(n=12)$ had the disease diagnosed during antenatal period in the index pregnancy, while evaluating for anemia or jaundice (Table 2). Of the newly diagnosed 12 cases, 7 had sickle cell anemia and 5 had sickle cell trait.

Two women with sickle cell anemia diagnosed in the index pregnancy were multigravidae with no maternal morbidity in the previous pregnancy other than mild anemia, but with low birth weight baby for one and recurrent abortions for the other. Of the sickle cell trait patients diagnosed in the index pregnancy, 4 were primigravidae with no previous symptoms and one was a multigravida with a previous uneventful pregnancy.

Table 2: SCD diagnosed in the index pregnancy.

\begin{tabular}{|lll|}
\hline Genotype & Primigravida & Multigravida \\
\hline HbSS & 5 & 2 \\
\hline HbAS & 4 & 1 \\
\hline
\end{tabular}

The most significant obstetric complication noted during pregnancy was hypertension (pre-eclampsia and gestational hypertension) and its complications like eclampsia and HELLP syndrome (Table 3). Antepartum eclampsia occurred in 2 women, while intrapartum and postpartum eclampsia occurred in one each. Intrauterine growth retardation (IUGR) was observed in more than one third of the women in the study population. Ultrasonogram finding of oligohydramnios was observed in 13 women $(18.06 \%)$ of which 8 showed abnormal flow in umbilical and middle cerebral artery Doppler. Gestational diabetes and preterm labour pain had almost similar rate of occurrence as in the general population attending the institution, while abruptioplacenta had a slightly high incidence. There were no cases of PROM, placenta previa and malpresentations.

Table 3: Obstetric complications.

\begin{tabular}{|c|c|c|c|c|c|}
\hline \multirow{2}{*}{ Complication } & \multicolumn{4}{|c|}{ Frequency } & \multirow{2}{*}{ Percentage } \\
\hline & HbSS & HbAS & HbS- $\beta$ thalassemia & Total & \\
\hline Previous perinatal loss & 8 & 1 & - & 10 & 13.88 \\
\hline Previous miscarriage & 4 & 2 & - & 6 & 8.33 \\
\hline Pre-eclampsia & 6 & 2 & - & 8 & 11.11 \\
\hline Gestational hypertension & 8 & 4 & - & 12 & 16 \\
\hline Eclampia & 4 & - & - & 4 & 5.56 \\
\hline HELLP syndrome & 2 & 1 & - & 3 & 4.16 \\
\hline GDM & - & 2 & - & 2 & 2.78 \\
\hline IUGR & 16 & 11 & 1 & 28 & 38.89 \\
\hline Oligohydramnios & 8 & 5 & - & 13 & 18.06 \\
\hline Preterm labour pain & 3 & 3 & - & 6 & 8.33 \\
\hline Abruption & 1 & 1 & - & 2 & 2.78 \\
\hline
\end{tabular}

Table 4: Non-obstetric complications.

\begin{tabular}{|c|c|c|c|c|c|}
\hline \multirow{2}{*}{ Complication } & \multicolumn{4}{|c|}{ Frequency } & \multirow{2}{*}{ Percentage } \\
\hline & HbSS & HbAS & HbS- $\beta$ thalassemia & Total & \\
\hline Anemia & 39 & 15 & 1 & 55 & 76.38 \\
\hline Vasoocclusive crisis & 13 & - & - & 13 & 18.05 \\
\hline Acute chest syndrome & 4 & - & - & 4 & 5.56 \\
\hline Bone crisis & 6 & - & - & 6 & 8.33 \\
\hline Hemolytic crisis & 2 & - & - & 2 & 2.78 \\
\hline Urinary tract infection & 5 & 1 & - & 6 & 8.33 \\
\hline Pneumonia & 3 & 1 & - & 4 & 5.56 \\
\hline
\end{tabular}

The commonest medical complication observed in these women during pregnancy was anemia (Table 4) defined as hemoglobin level less than $11 \mathrm{gm} \% .76 .38 \%$ of SCD women had anemia of which 46 had mild to moderate anemia $(\mathrm{Hb}=7-10.9 \mathrm{gm} \%)$, while 9 had severe anemia 
( $\mathrm{Hb}<7 \mathrm{gm} \%)$. All patients with severe anemia belonged to $\mathrm{HbSS}$ category. One woman with severe anemia was admitted with cardiac failure. Antenatal transfusions for correction of anemia was required in $62.5 \%(n=45)$ of the total women ( $38 \mathrm{HbSS}$ and $7 \mathrm{HbAS})$.

24 patients $(33.33 \%)$ had 3 or more transfusions during pregnancy. Exchange transfusion was required antenatally in 4 patients with acute chest syndrome. 27 women ( $1 \mathrm{HbSS}, 1 \mathrm{HbS}-\beta$ thalassemia and $25 \mathrm{HbAS}$ ) needed no antenatal or postnatal transfusions.

Vasoocclusive crisis occurred in $13(18.05 \%)$ women of which 4 had acute chest syndrome. There were 6 women with bone crisis, 2 with hemolytic crisis and 1 with splenic crisis. Crisis was detected only in HbSS women. Jaundice which is a usual accompaniment of SCD was present in $16 \mathrm{HbSS}$ women. About $8.33 \%$ women (5 HbSS and $1 \mathrm{HbAS}$ ) had urinary tract infection and $5.56 \%$ (3 HbSS and $1 \mathrm{HbAS}$ ) had pneumonia. Other infectious pathology noted were peridental abscess in one HbSS woman and cellulitis of both lower limbs in another during antenatal period. There was one woman on anti- tuberculosis treatment for pulmonary tuberculosis, who was also a Hepatitis B carrier.

Labour was induced in $29.67 \%(n=21)$ of the SCD women most of them $(n=15)$ for IUGR and hypertensive complications. Sickle cell crisis with worsening maternal condition was the indication for induction of labour in 2 patients. Two women each were induced for intrauterine fetal demise and postdatism respectively.

Majority of the women (75\%) in the study population had term delivery (Table 5). $18.06 \%$ patients had delivered preterm, of which 4 were induced and 3 had elective preterm caesarean section for obstetric indications.

One patient who was induced for HELLP syndrome underwent preterm emergency LSCS for failed induction. Only $6(8.33 \%)$ patients had spontaneous onset of preterm labour. Of those who delivered past date, two went into labour spontaneously, two had induced labour and one (previous CS) underwent elective caeserean section.

Table 5: Gestational age at delivery.

\begin{tabular}{|lllll|}
\hline Gestational age & Vaginal delivery & Caesarean section & Total & Percentage \\
\hline Preterm $(<37$ weeks $)$ & 9 & 4 & 13 & 18.06 \\
\hline Term $(37-40$ weeks $)$ & 35 & 19 & 54 & 75 \\
\hline Past date $(>40$ weeks) & 4 & 1 & 5 & 6.94 \\
\hline
\end{tabular}

Two third of the total women $(\mathrm{n}=48 ; 66.67 \%)$ delivered vaginally, while $24(33.33 \%)$ underwent caesarean section. Most common indication for caesarean section was previous caesarean $(54.16 \%)$, followed by fetal distress and Doppler abnormalities associated with intrauterine growth restriction (Table 6).

Elective primary caesarean section had to be done in 3 women with severe IUGR showing absent or reversal of flow in umbilical artery Doppler study.

Table 6: Indications for caesarean section.

\begin{tabular}{|lll|}
\hline Indication & Frequency & Percentage \\
\hline Previous caeserean & 13 & 54.16 \\
\hline $\begin{array}{l}\text { IUGR with abnormal } \\
\text { doppler }\end{array}$ & 3 & 12.5 \\
\hline Fetal distress & 3 & 12.5 \\
\hline $\begin{array}{l}\text { Failed induction for } \\
\text { HELLP/preeclampsia/ }\end{array}$ & 4 & 16.67 \\
IUGR & & 4.17 \\
\hline Intrapartum eclampsia & 1 & \\
\hline
\end{tabular}

Atonic PPH occurred in one woman (1.39\%) with sickle cell anemia, which was controlled by medical management and blood transfusion. None of the women had thromboembolism in the antepartum or postpartum period. Heparin was given prophylactically to all women with $\mathrm{HbSS}$ in the postpartum period.

There were no cases of maternal mortality. The number of low birth weight babies were high $(56.94 \%)$ due to IUGR and prematurity (Table 7 ) and $12.5 \%$ had very low birth weight of less than $1.5 \mathrm{~kg}$. Mean birth weight was $2.1 \mathrm{~kg}$.

Table 7: Birth weight.

\begin{tabular}{|lll|}
\hline Birth weight & Frequency & Percentage \\
\hline$>2.5 \mathrm{~kg}$ & 31 & 43.06 \\
\hline $1.5-2.5 \mathrm{~kg}$ & 32 & 44.44 \\
\hline$<1.5 \mathrm{~kg}$ & 9 & 12.5 \\
\hline
\end{tabular}

Table 8: Perinatal outcome.

\begin{tabular}{|lll|}
\hline Perinatal complication & Frequency & Percentage \\
\hline Prematurity & 13 & 18.06 \\
\hline Low birth weight & 41 & 56.94 \\
\hline Five-minute Apgar $<7$ & 10 & 14.49 \\
\hline Neonatal ICU admission & 21 & 31.88 \\
\hline Perinatal mortality & 5 & 6.94 \\
\hline
\end{tabular}

Of the 72 women, $69(95.83 \%)$ had live births, 2 had intrauterine fetal demise and one had still birth. Low 
Apgar score was detected in $14.49 \%(n=10)$ of live born babies. Due to prematurity, low birth weight and respiratory distress, 21 babies needed admission to the neonatal ICU for further monitoring and care (Table 8).

There were two neonatal deaths due to perinatal birth asphyxia. The perinatal mortality rate was $69.4 / 1000$ deliveries. None of the babies had congenital anomalies.

\section{DISCUSSION}

Kerala is one of the high prevalence states for SCD and the disease is commonly seen in scheduled tribes. ${ }^{13}$ It has been reported that the sickle cell disease is $30 \%$ prevalent in North Kerala especially in the hilly tracts of Wayanad district. $^{14}$ Our centre (Government Medical college, Kozhikode, Kerala) is the only tertiary care referral centre in the public sector which caters to the districts of Wayanad and the Nilgiris which has the maximum prevalence for SCD in South India. With more awareness about the disease and with better treatment options and facilities, more females are reaching the child bearing age. This has led to an increase in the number of pregnant SCD patients (mostly tribal) attending our institution. In this study, sickle cell disease was found in only $0.15 \%$ of the women delivering in our institution which was similar to the $0.2 \%$ in Port Harcourt, Nigeria where there is a predominance of SCD. ${ }^{12}$ This low incidence may be because the tribal antenatal women with complications only, are attending this institution and those with undiagnosed SCD especially the ones with sickle cell trait (without any symptoms) may be delivering in their nearby health centres.

Though our SCD patients also had a higher incidence of miscarriages and perinatal mortality in previous pregnancies, it was not as high (above 20\%) as reported. ${ }^{10,15}$

Pregnancy in sickle cell women is at high risk for maternal and fetal complications than in general population. ${ }^{9,15}$ Similar to many other studies, we found that obstetric complications like preeclampsia and gestational hypertension were high in women with sickle cell disease with a higher risk in homozygous (HbSS) genotype. ${ }^{9-11,15-19}$ Eclampsia which is a life threatening complication of preeclampsia was reported to be 10 times high in HbSS women. ${ }^{17}$ This study also showed a higher incidence of eclampsia in consistent with an earlier metaanalysis and also reports from other states of India. ${ }^{9,11,20}$ Intrauterine growth restriction was seen in more than onethird of the SCD women and such a higher incidence was shown in literature. ${ }^{17,18,21}$ Chronic maternal anemia and hypertension in pregnancy resulting in reduced placental perfusion is the most likely reason for intrauterine growth restriction. But, unlike reported earlier, GDM and was comparable with normal population. ${ }^{15,17}$

As previously reported, present study showed a $100 \%$ incidence of moderate to severe anemia in $\mathrm{HbSS}$ antenatal women; while there were studies with anemia as less as $8.4 \% .^{9,22,17}$ But we found anemia in only $46.88 \%$ of HbAS women as against the $95 \%$ in earlier reports. ${ }^{11}$ More than $60 \%$ of sickle cell deliveries required blood transfusion with about a third of the total patients requiring three or more transfusions which was very high comparing with $52.7 \%$ transfusions as reported recently by Desai $G$ et al with only $8.4 \%$ requiring 3 or more transfusions. ${ }^{20}$

Sickle cell crisis, one of the acute complication of SCD has been shown to increase antepartum hospital admissions. ${ }^{19,21}$ Pregnancy has been shown to exacerbate sickle cell crises with as high as $100 \%$ incidence of vasoocclusive crisis in pregnant women with SCD. ${ }^{12,19,22,23}$ Pinto $\mathrm{S}$ et al has reported vasoocclusive crisis in $61.7 \%$ of pregnant SCD patients and acute chest syndrome as high as $29.4 \% .{ }^{15}$ However, about $18.05 \%$ of vaso occlusive crisis and $5.56 \%$ of acute chest syndrome were observed in this study, which is consistent with an observational study in French Guiana where SCD has an incidence of 1 in 235 births. ${ }^{10}$ Infective complications observed in this study were mainly urinary tract infections and pneumonia which were controlled without further complications. ${ }^{17,19,22}$ Infections was the cause of maternal mortality in $82 \%$ of SCD women in Tanzania. ${ }^{24}$ Unlike many studies which showed a higher rate of malarial infections in pregnant women with SCD, we did not have a single patient with malaria. ${ }^{12,22,24}$

Women with sickle cell hemoglobinopathy have been found to have a higher risk for preterm delivery. ${ }^{9-12,15-}$ 17,20,21 According to Desai G et al and Ugobama et al, the incidence of preterm birth was as high as 44-45\%. ${ }^{12,20}$ Our incidence was $18.06 \%$ which was consistent with the 2-fold increased risk in SCD women. ${ }^{9}$ Caesarean deliveries were also more either due to maternal or fetal complications. ${ }^{10,11,16}$

SCD in pregnancy has been associated with low birth weight (LBW) and was observed in about $50 \%$ pregnancies by Ugboma et al. ${ }^{12}$ There was a nearly fourfold increased risk of infants being born small for gestational age $\left(<10^{\text {th }}\right.$ centile) in women with $\mathrm{HbSS}$ disease (RR, 3.72; 95\% CI, 2.32-5.98) when compared with non SCD women. ${ }^{9}$ Factors responsible for this may be lower gestational age at delivery, maternal anemia, preeclampsia and intrauterine growth restriction. We had $56.94 \%$ babies less than $2.5 \mathrm{~kg}$ at birth similar to the higher rates observed earlier. ${ }^{11,16,17,20-22,24}$ Low Apgar score of $11 \%$ by Silva-Pinto et al and $34.5 \%$ by Muganyizi et al has been reported in babies born to SCD mothers, while we had $14.49 \%$ babies with low Apgar. ${ }^{16,24}$ Because of prematurity, low birth weight and perinatal asphyxia due to IUGR, there was a high rate of neonatal ICU admissions. ${ }^{10,17}$

Very alarming maternal mortality with 29 times higher risk than non SCD patients have been reported by Muganyizi et al of which $82 \%$ were due to infections. ${ }^{24}$ 
Acute chest syndrome, sepsis and multiorgan failure have attributed to the higher incidence of maternal losses among SCD women. ${ }^{9,12,15,19,22}$ Despite many lifethreatening complications, there were no maternal mortality in present study. ${ }^{10,21}$ This may be due to the improvement in the primary health care facilities and early reference of the SCD patients from the remote tribal areas to our institution. Also, the survival rate of sickle cell anemia appears to be higher in Kerala compared to other Indian states. ${ }^{14}$ High risk of still births and neonatal mortality has been reported in India as well as in other countries in pregnancies complicated by sickle cell disease..$^{9,11-13,15,17,22} \mathrm{We}$ also had a high perinatal mortality primarily due to growth restriction. But, few previous studies have shown no increase in the perinatal mortality. ${ }^{10,21}$

\section{CONCLUSION}

This study has identified an increased morbidity in pregnancy in women with SCD due to hypertensive disorders, aggravation of anemia and sickle cell crises. Perinatal outcome was also found to be adverse with increased perinatal mortality. As most of the study population was identified to belong to the scheduled tribe population, active screening programmes need to be undertaken in the public health sector to identify women with sickle cell disease. Also, measures should be taken to give better care for them through improved preconception awareness and counselling about the disease, early and better antenatal care, prompt identification and treatment of complications and early referral to tertiary care facilities

\section{Funding: No funding sources \\ Conflict of interest: None declared \\ Ethical approval: Not required}

\section{REFERENCES}

1. Stuart MJ, Nagel RL. Sickle-cell disease. Lancet. 2004;364:1343-60.

2. Rees DC, Williams TN, Gladwin MT. Sickle-cell disease. Lancet. 2010;376(9757):2018-31.

3. Piel FB, Patil AP, Howes RE, Nyangiri OA, Gething PW, Williams TN, et al. Global distribution of the sickle cell gene and geographical confirmation of the malaria hypothesis. Nat Commun. 2010;1:104.

4. Piel FB, Hay SI, Gupta S, Weatherall DJ, Williams TN. Global burden of sickle cell anaemia in children under five, 2010-2050: modelling based on demographics, excess mortality, and interventions. PLoS Med. 2013;10(7):e1001484.

5. Colah RB, Mukherjee MB, Martin S, Ghosh K. Sickle cell disease in tribal populations in India. Indian J Med Res. 2015;141:509-15.

6. Odièvre $\mathrm{MH}$, Verger E, Silva-Pinto AC, Elion J. Pathophysiological insights in sickle cell disease. Indian J Med Res. 2011;134:532-7.
7. Hematological Disorders. In: Cunningham FG, Leveno KJ, Bloom SL, Spong CY, Dashe JS, Hoffman BL, et al, eds. Williams Obstetrics $24^{\text {th }}$ ed. Mc Graw Hill; 2014:1101-8

8. Sparkenbaugh E, Pawlinski R. Interplay between coagulation and vascular inflammation in sickle cell disease. Br J Haematol. 2013;162(1):3-14.

9. Oteng-Ntim E, Meeks D, Seed PT, Webster L, Howard J, Doyle P, et al. Adverse maternal and perinatal outcomes in pregnant women with sickle cell disease: systematic review and meta-analysis. Blood. 2015;125:3316-25.

10. Elenga N, Adeline A, Balcaen J, Vaz T, Calvez M, Terraz A, et al. Pregnancy in sickle cell disease is a very high-risk situation: an observational study Obstet Gynecol Int. 2016;2016:9069054.

11. Anju SS, Pralhadrao ZS. Pregnancy outcome in women with sickle cell disease/trait. J Obstet Gynecol India. 2005;55(5):415-8.

12. Ugboma HAA, George IO. sickle cell disease in pregnancy: maternal and fetal outcome in Port Harcourt. Nigeria Br J Med Med Res. 2015;7(1):404.

13. Balgir R. Epidemiology, population health genetics and phenotypic diversity of sickle cell disease in India. Internet J Biol Anthropol. 2007;1(2):1-26.

14. Feroze M, Aravindan KP. Sickle cell disease in Wayanad, Kerala: gene frequencies and disease characteristics. Nat Med J India. 2001;14(5):267-70.

15. Silva-Pinto AC, Ladeira SD, Brunetta DM, Santis GC, Angulo ID, Covas DT. Sickle cell disease and pregnancy: analysis of 34 patients followed at the Regional Blood Center of Ribeirão Preto, Brazil. Brazilian J Hematol Hemotherapy. 2014;36(5):32933.

16. Ngô C, Kayem G, Habibi A, Benachi A, Goffinet F, Galactéros F, et al. Pregnancy in sickle cell disease: maternal and fetal outcomes in a population receiving prophylactic partial exchange transfusions. Obstet Gynecol Survey. 2011;66(2):73-4.

17. Wilson NO, Ceesay FK, Hibbert JM, Driss A, Obed SA, Adjei AA, et al. stiles pregnancy outcomes among patients with sickle cell disease at Korle-Bu Teaching Hospital, Accra, Ghana: Retrospective cohort study. Am J Trop Med Hyg. 2012;86(6):93642.

18. Al Jama FE, Gasem $\mathrm{T}$, Burshaid S, Rahman J, Al Suleiman SA, Rahman MS. Pregnancy outcome in patients with homozygous sickle cell disease in a university hospital, Eastern Saudi Arabia. Arch Gynecol Obstet. 2009;280(5):793-7.

19. John CO, Orazulike N, Ijeoma C. Feto-maternal outcome in patients with sickle cell anaemia at the University of Port Harcourt Teaching Hospital, Port Harcourt, Nigeria: a ten-year retrospective review. Int J Obstet Gynecol. 2015;3(4):95-9.

20. Desai G, Anand A, Sha P, Shah S, Dave K, Bhatt H, et al. Sickle cell disease and pregnancy outcomes: a study of the community-based hospital in a tribal 
block of Gujarat. India J Health Population Nutrition. 2017;36:3.

21. Sun PM, Wilburn W, Raynor BD, Jamieson D. Sickle cell disease in pregnancy: twenty years of experience at Grady Memorial Hospital, Atlanta, Georgia. Am J Obstet Gynecol. 2001;184(6):112730 .

22. Ocheni S, Onah HE, Ibegbulam OG, Eze MI. Pregnancy outcomes in patients with sickle cell disease in Enugu, Nigeria. Niger $\mathbf{J}$ Med. 2007;16(3):227-30.

23. Villers MS, Jamison MG, De Castro LM, James AH. Morbidity associated with sickle cell disease in pregnancy. Am J Obstet Gynecol. 2008;199:125.
24. Muganyizi PS, Kidanto H. Sickle Cell disease in pregnancy: trend and pregnancy outcomes at a tertiary hospital in Tanzania. PLoS One. 2013;8(2):e56541.

Cite this article as: D'Couth $\mathrm{S}$, Kalam $\mathrm{S}$.

Fetomaternal outcome in sickle cell

hemoglobinopathy in a tertiary care centre of North

Kerala, India. Int J Reprod Contracept Obstet

Gynecol 2017;6:5299-305. 